\title{
The Benevolent Serpent Deities At the Underworld Book
}

\author{
By
}

\author{
DR/Mariana Abd Elsayed Asham
}

\begin{abstract}
The serpent was a dominant theme in the culture of the ancient Egyptians. In the physical world, serpents were feared and respected. The ancient Egyptians were aware of the danger that serpents presented to their day-to-day life. They could harm, paralyze or kill and they demanded the respect of the ancient Egyptians. The Egyptian cobra, horned viper, and black-necked spitting cobra were all a very real danger to the ancient Egyptians. Venom from any of these three snakes could lead to paralysis or death. ${ }^{(1)}$

The serpent plays an extraordinarily important and extremely diverse role as a symbolic animal. The primary characteristics that gave the serpent its symbolic significance were the special place it occupies in the animal kingdom (movement over the ground without legs, living in holes in the ground, yet slipping out of eggs like a bird), its cold, slick and shiny exterior, its poisonous bite and its venom that can be used for medicinal purposes, as well as its periodic shedding of its skin. ${ }^{(2)}$

\section{Methodology}

This paper aims to be a descriptive and an analytical study of the benevolent serpent deities at the Underworld Books. The Appellation of the serpent according to different texts; the iconography; the Divinity and Symbolic Value of the Serpent; his cult and relation between him and other gods and how he was linked to the sun god. ${ }^{(3)}$
\end{abstract}

Keywords

The Serpent, The Underworld Books, Divinity and Symbolic value of the Serpent.

$\left.{ }^{1}\right)$ P.F. Houlihan, The Animal World of the Pharaohs (New York,1996), 168.

$\left({ }^{2}\right) \mathrm{U}$. Becker, The Continuum Encyclopedia of Symbols (London, 1994), 343; A. Alexandridis, Wenn Götter Lieben, Wenn Götter Strafen, Mensch und Tier in der Antike (Leipzig, 2008), 285-311.

$\left({ }^{3}\right)$ C.L. Geddes\&G.Grosset, Ancient Egypt: Myth\&History (Scotland, 1997), 74. 


\section{The benevolent Serpent Deities at the Underworld Book}

\section{Historical Background}

Thus, local wide fauna of birds, crocodiles, serpents, turtles, frogs, plus cattle, dogs, cats and other domesticated animals were considered to be the living images of a particular god or goddess and a natural and indestructible of the environment in which people lived. ${ }^{(4)}$ Animal cults in general may have been motivated first of all by man's fear of animals and their usefulness. Animals became media of revelation and also the bearers of supernatural powers andarchetypal qualities, hence the fact for example, that the bull symbolized the power of generation, the cow motherhood and the serpent symbolized the fertility. ${ }^{(5)}$

Before the beginning of history, the ancient Egyptians took the serpent as a Totemian ${ }^{(6)}$ symbol for protecting them from evil forces and directing

$\left({ }^{4}\right)$ F. Martin, Tierkulte im Pharaonischen Ägyptischen Ägypten, Ägyptologie und Kulturwissenschaft VI (München, 2013), 226.

$\left({ }^{5}\right)$ E. Linda, Animal Behavior in Egyptian Art: Representation of the Natural World in Memphite Tomb Scenes, Australian Centre for Egyptology (Australian Centre for Egyptology, 2010), 77. TheriomorphicDeties: Ancient Egyptian Gods are not inherently Theriomorphic. Popular understanding of the gods of Ancient Egypt associate their worship with a barbaric and primitive focus on totems and animal worship; Herodotus is a prime example, as are Roman writers like Horace, and somehow the tradition continued to this day.Egyptian logic works rather differently than ours; there is no real concept of paradox. Thus, there is worship of Sobek$\mathrm{Ra}$, who is both Sobek and Ra individually, rather than a combination of the two. Same with animals: Horus is a god and a falcon, but not a falcon god, celebrated as a god in his aspect as falcon rather than a god who is a falcon (G. Jackal, Theriomorophic Egyptian Gods, (New York, 2000), 1; A. Alexandridis, Mensch und Tier in der Antike, Reichert Verlag, (Wiesbaden, 2008), 76; A. Alexandridis, Animals, Oxford Encyclopedia in Ancient Greece and Rome I (Oxford, 2010), 108-112.

$\left({ }^{6}\right)$ Totem: It is known that, the social and political ties over the Nile Valley were built according to the tribe or the horde association, every tribe was belonged to certain Totem from the animal world or the Botanist, so, the Egyptians expected that the president of every tribe is an offspring for its Totem. And after the transition from the tribal system to the regional one, they were under considered of that every province had its own Totem and the divinity of its nation. And after the merge of these provinces under one 
its harm and violence to their enemies. So, it is seen as a sacred power and eternal symbol that crossed every path in the myth, culture and history of man. Sometimes these mythic beasts appear as ordinary serpents. At other times, they take on magical or monstrous forms. They have long been associated with good as well as with evil, representing life and death, creation and destruction. ${ }^{(7)}$

From the serpent, a great variety of symbolisms can be realized; among them: in general symbolism, androgyny, circle, convalescence, cunning, danger, death, deceit, destruction, divine emanation, evil, false appearance fertility, guardianship, generation, grief, health, intelligence, jealousy, lasciviousness, malice, materialism, misfortune, phallus, pleasure, power, prophecy, prudence, renewal, revenge, self- creation self -indulgence, self sustenance sensation, sensuality, sin, subtlety, temptation, treachery, the unfathomable, universe circle, vexations, vice, wiliness, wisdom, worldliness, emblem of lighting, physicians, and witchcraft. ${ }^{(8)}$ Its symbolism showed also the most glaring contrasts. Its speed slithering beauty, its mystery and dangerousness evoked worship and abhorrence. As a chthonic (9) animal the serpent was one of the life-creating powers. ${ }^{(10)}$

The serpent is one of the forms of Atum, believed to be a primeval creator deity. He was the serpent who continued to live season after season. In a fascinating dialogue with Osiris, the Egyptian god of the underworld

kingdom, the Totem of the kings' tribe became the Totem and divinity of all Egypt:

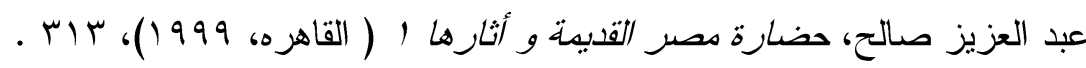

$\left.{ }^{7}\right) \mathrm{J} . \mathrm{Q}$. Friedrich, The Animals of the Desert and the Return of the goddess, Desert Animals in the Eastern Sahara Colloquium Africanum 4 (Köln, 2009), 341-361.

$\left({ }^{8}\right)$ G.Jobes, Dictionary of Mythology (London,1961), 20.

(9)Chthonic: Chthonic "in, under, or beneath the earth", from chthōn "earth"; pertaining to the Earth; earthy; subterranean), apart from its literal translation meaning 'subterranean', its historical or interpretive definition designates, or pertains to, deities or spirits of the underworld, especially in relation to Greek religion. The Greek word khthon is one of several for "earth"; it typically refers to the interior of the soil, rather than the living surface of the land (as Gaia or Ge does) or the land as territory. It evokes at once abundance and the grave (T. Del Valle, Gendered Anthropology (London, 1993), 108.

$\left({ }^{10}\right)$ M. Lurker, An Illustrated Dictionary of the Gods and Symbols of Ancient Egypt (London, 1982), 98. 


\section{The benevolent Serpent Deities at the Underworld Book}

and of final judgment. ${ }^{(11)}$ Atum predicts the destruction of the world that he created and his own reversion back to the form of serpent.

According to Henri Frankfort, "The primeval serpent.....survives when everything else is destroyed at the end of time". Thus the serpent was strongly and continually associated with creation and eternal existence in the ancient Egyptian ethos. They portrayed life itself by the image of the rearing serpent, and a serpent biting its tail was a common Egyptian emblem for "eternity" (Fig.1, 2).

Clark added that the concept of life in ancient Egypt is represented in the automatic or soft movement which bases to move up. It is related with the upright of the serpent to the top with the appearance of the lotus flower from the deeply water and flourishing its leaves with the first sun light. From this point, the serpent became the symbol of life, organization, royalty, and legitimacy ${ }^{(13)}$

Clark clarifies that the main activities and symbols of the serpents in ancient Egyptian beliefs as follows: the creator from one hand and the monster who should be controlled from the other hand. The first is seen in both of the serpent $z 3-t 3$. It is a divine serpent god weaves the universe in several folds or one fold putting his tail at his mouth and guards the underworld. And Neheb-kзw, the god of water who lives inside the caves where the Nile flood springs from. While the second is seen in the great enemy of Ra who personifies the powers of darkness Apophis who should be defeated daily. ${ }^{(14)}$

Hornung added also that the full circle of the serpents' body(fig.3) is envisaged as a separation between existence and nonexistence. According to the Amduat ${ }^{(15)}$ and the Book of Gates ${ }^{(16)}$, the serpent was the hours' guardian

$\left({ }^{11}\right)$ S. Moscati, The Face of the Ancient Orient Garden City (Chicago, 1962), 125-127.

$\left({ }^{12}\right)$ H. Frankfort, Kingship and the Gods (Chicago, 1962), 145.

$\left({ }^{13}\right)$ S. Johnson, The Cobra Goddesses of Ancient Egypt: Pre-dynastic, Early Dynastic, and Old Kingdom Period (London, 1990), X.

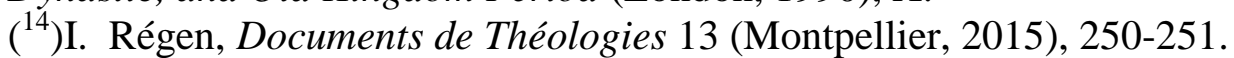

$\left({ }^{15}\right)$ The Book of Amduat: is described as the place, where the souls; gods; shadows and spirits stand. So, it represents the knowledge of their power; what they do; their sacred rituals to Ra; the mysterious power; what is in the hours as well as their gods; what he says to them; the gates and the ways on which the great god passes; the movement of the hours and their gods; and of the powerful ones and the annihilated $(\mathrm{H}$. Kees, Totenglauben und 
as every nightly hour is guarded by a serpent god. It was often represented with four body folds to reflect the four cardinal points of the universe $2 \Omega_{(17)}$

The forms of serpents were sanctified by the Egyptians only limited in two forms: the first was the horned cobra which is a poisonous serpent. It was well-known as sandy serpent due to its presence of abundance in Aswan desert in particular at Kalabsha. It is immediately after biting man. ${ }^{(18)}$ While the second is known as the Uraeus which is considered more dangerous than the first and sends it's fiery breathes to the enemies of the king. For that reason it was place at the forehead of the king. One of those serpentine goddesses who decorated the crown of the king is Wadjet, the protector goddess of the sun god. ${ }^{(19)}$

\section{The Appellation of the Serpent:}

There is a general confusion with 'snake': even though in biology the term 'serpent' is usually preferred for the larger kinds. Literature has never made that distinction; therefore, snake and serpent have been put under one heading. The other distinctive (the serpent being limbless, having scales) are not observed either: e.g. in old prints of the Paradise-scene the 'serpent' does

Jenseitvorstellungen der Alten Ägypter: Grundlagen und Entwicklung bis zum Ende des Mittleren Reiches (Berlin, 1956), 60.

$\left({ }^{16}\right)$ The Book of Gates: the original title of the Book of Gates is not attested. Although the structure of the book is quite similar to that of the Amduat, with twelve nocturnal divisions and a prologue depicting the western mountain. Each division consists of three registers, which represent respectively the celestial river and its two banks (A. Baumann, The Suffix Conjugation of Early Egyptian as Evidenced in the Underworld Books I (Chicago, 1998), 5.

${ }^{(17) E . ~ H o r n u n g, ~ D e r ~ A ̈ g y p t i s c h e ~ M y t h o s ~ v o n ~ d e r ~ H i m m e l s k u h: ~ E i n e ~}$ Ätiologie des Unvolkommenen Orbis Biblicuset Orientalis, vol. 46, Reclams Universal-Bibliothek (Göttingen, 1982), 178-179, fig.18.

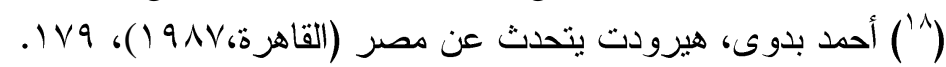

$\left({ }^{19}\right)$ M. Münster, Untersuchungen zur Göttin Isis vom Alten Reich bis zum Ende des Neuen Reiches, Muenchner Äegyptologische Studien 11 (Berlin,1986), 208;

$$
\text { أدولف إرمن، ديانة مصر القديمة (بV (9Vا، القاهرة)، } 07 .
$$




\section{The benevolent Serpent Deities at the Underworld Book}

have limbs, looking more like a lizard, or (even likelier) a 'dragon'; only when specific mention has been made of the kind. ${ }^{(20)}$

Serpents belong to the reptiles which is derived from the Latin word "Repto". While in the ancient Egyptian language. ${ }^{(21)}$ The family of serpents

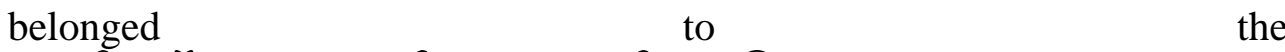

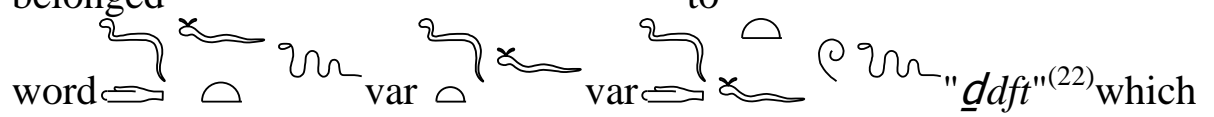

means "serpent", "serpentine", and "worm".

Then the determinative of the cobra form appeared with the " $k$ " sound like If $m f q$, "the Malakit" and "glorify". (23)

hqn, "worship" or

While the three-folded serpent

is used as a determinative for the

names of the serpent $n ? w^{24}$. Other name is mentioned $\longrightarrow$ rqrqthat means the "retiled". ${ }^{25)}$

The snake (serpens) takes its name because it creeps (serpere) by secret approaches. It crawls not with open steps but by tiny thrusts of its scales. But those animals that support themselves on four feet, like the lizard and the newt, are not snakes, but are called as it is said previously reptiles (reptile). Snakes are also reptiles, because they crawl (repere) on their stomach and breast. Of these animals there are as many poisons as there are

$\left({ }^{20}\right)$ W. AddeVries, Dictionary of Symbols and Imagery, North Holland (London, 1979), 515.

( (") ثناء محمود الرشيدي، الثعبان ومغزاه عند المصري القديم من البدايات الأولى وحتى نهاية

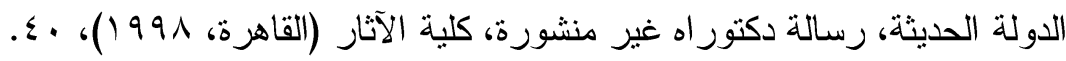

$\left({ }^{22}\right)$ A. Erman\& H. Grapow, Das Wörterbuch der Ägyptische Sprache V (Berlin, 1922), 633, 5a.

$\left({ }^{23}\right)$ A. Erman\& H. Grapow, Das Wörterbuch der Ägyptische Sprache III (Berlin, 1971) 178, 1 b.

$\left({ }^{24}\right)$ A. Erman\& H. Grapow, Das Wörterbuch der Ägyptische Sprache II (Berlin, 1971), 207, 7a.

$\left({ }^{25}\right)$ A.Erman\&H.Grapow, 1971, Das Wörterbuch II, 485, 7a; D. Burston, Freud, the Serpent \& the Sexual Enlightenment of Children III, (New York, 1994), 205-519. 
kinds, as many varieties of danger as there are of appearance, and as many causes of pain as there are colors. ${ }^{(26)}$

A Brooklyn papyrus ${ }^{(27)}$ is manual for the treatment of snakebite lists the names of thirty-seven types of serpent distinguished by the ancient Egyptians. It gives a physical description of each serpent, along with precise descriptions of symptoms, whether or not the wound is mortal. And the name of god or goddess of which the serpent is considered to be a manifestation following the list of serpents is a list of remedies. One of the serpents the Egyptians had to contend with was the horned viper, who is rasping coils make a sound. ${ }^{(28)}$

Despite the large number of serpents' names in ancient Egyptian texts and the multiplicity of forms in various inscriptions. Noticed that, it is difficult to do an inventory of the serpents in Egypt since ancient times and determine its factions; colors and the environment in which they were found. However, serpents are mentioned in Pyramid Texts, Coffin Texts,

$\left({ }^{26}\right)$ The Bible interchanges the words dragon and serpent liberally. Draco, the dragon, is usually portrayed with feet and believed to be the 'old serpent', the tempter of Eve in the Garden (H. Bayley, The Lost Language of Symbolism (London,1995), 219).

$\left.{ }^{27}\right)$ It is known also as the "Brooklyn Medical Papyrus" dating from ancient Egypt and is one of the oldest preserved writings about medicine and ophiology. The manuscript is dated to around $450 \mathrm{BC}$ and is today kept at the Brooklyn Museum in New York. It consists of a scroll of papyrus divided into two parts with some parts missing; its total length is estimated to $175 \times 27 \mathrm{~cm}$. The text is on the recto side. The different numbers refer to the upper part and the lower part of the scroll. The manuscript is a collection, the first part systematically describing a number of different snakes and the second part describing different treatments for snakebites. The manuscript also contains treatments of scorpion bites and spider bites. A remedy for a bite could combine both physical and magical or religious practices. A bite victim might be prescribed to chew on a mixture of beer and onion or a priest could symbolically cast the poison on the ground and apply a "knife treatment" to the wound (J.N. Francis, Ancient Egyptian Medicine (Oklahoma, 2002), 40; J. Allen, The Art of Medicine in Ancient Egypt (London, 2005), 11; J.F. Nunn, Ancient Egyptian Medicine (Oklahoma, 1966), 144).

$\left({ }^{28}\right) \mathrm{N}$. Hansen, Amphibians and Reptiles, Oxford Encyclopedia of Ancient Egypt 1, ed. D. Redford (Oxford, 2001), 74-75. 


\section{The benevolent Serpent Deities at the Underworld Book}

Book of Dead, and other religious books dating to the New Kingdom. They do not mention their anatomical description to clarify their faction and colors. ${ }^{(29)}$ But there is what is called by Brooklyn papyrus which dates back to $30^{\text {th }}$ dynasty. it was found at Brooklyn museum that provided to some extent a detailed book about the serpent in ancient Egypt including their names; forms; locations and its severity. ${ }^{(30)}$

Serpents appear in several different forms in ancient Egyptian hieroglyphic writing and art. This chapter will begin with a discussion on the general use of serpents in the ancient Egyptians " writing and art. It is written in the Egyptian language with many forms for instance, the attacker

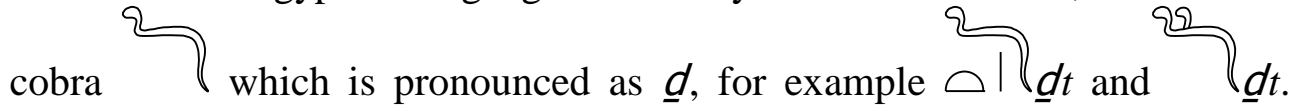
When the cobra is found fixed on the front part of the crown, it is written as QR

that refers to one of the serpentine goddesses. ${ }^{(31)}$ While it is seen

standing $\checkmark$ on the forehead of the pharaoh, it is used as a determinative for the cobra goddesses like

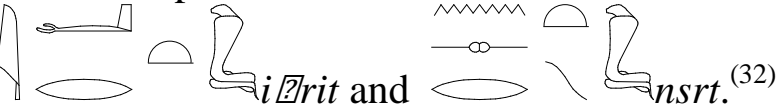

It is appeared also with the name of some old Egyptian towns, there is what is called the serpent province $f(3 \overbrace{}^{2} w j \underline{d}$ twhere the "Fields that Ra loved" is found. While along the Nineteenth Dynasty, the serpent was used as a determinative for Luxor; Habu; Dandara; Edfu; Buto. And it became common also at both of the late and Greece periods. ${ }^{(33)}$

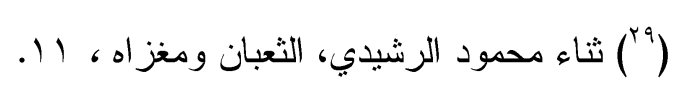

$\left({ }^{30}\right)$ S. Sauneron, Papyrus Magique Illustre de Brooklyn, du Brooklyn Museum, (New York, 1980), 137.

$\left.{ }^{31}\right) \mathrm{K} . \quad$ Sethe, Die AltaegyptischePyramidentexte: nach den Papierabdrücken und Photographien des Berliner Museums (Leipzig, 1922), 226, 276, 375, 727; A. De Buck, The Egyptian Coffin Texts VII (Chicago, 1961), $160 \mathrm{f}, 369 \mathrm{~b}, 378 \mathrm{f}$.

$\left({ }^{32}\right)$ A. Gardiner, Egyptian Grammar (Oxford, 1927), 476.

$\left({ }^{33}\right)$ K. Sethe, Die Altaegyptische Pyramidentexte,729 a; A. Erman\& H. Grapow, Wörterbuch der Aegyptischen II, 213, 6. 
While the determinative of the serpent with four-folded body

appeared at the Late Period. It was used as a determinative for the in warms $\triangle \quad$ fnt, "warm" or $\bigcirc \quad|\quad|$ fntw, "warms" the kind which devoured the deceased through the underworld. ${ }^{(34)}$

The hieroglyph inscription of the serpents' name corresponds phonetically to the letter $Z$ is arepresentation of its movement. Like the sign of the slug, or horned serpent (phonetically equaled to $F$ ). This hieroglyph refers to primogenital and cosmic forces. Generally speaking, the names of the goddesses are determined by signs representing the serpent as it is said previously - which is tantamount to say that it is because of woman that the spirit has fallen into matter and evil. The serpent is also used, as are other reptiles, to refer to the primordial - the most primitive strata of life.In the Book of the Dead (XVII), the reptiles are the first to acclaim Ra when he appears above the surface of the waters of Nut. ${ }^{(35)}$

Also, it is known that the letter $S$ also was one of the oldest symbols of serpent hood, both in its shape and in its sibilant sound. It was one of the oldest symbols of female power. Woman and serpent together were considered holy, since both seemed to embody the power of life ${ }^{(36)}$. According to the Egyptian belief, the serpent was the mother of all gods who is painfully familiar in all the Mosic record as a female animal. A Greco-Egyptian writer of the Ptolemaic period "Horapollo", does, indeed, assign a motive for the superstation; and his language is sufficiently curious to excuse the quoting of it accordingly. So it would be obvious that, from a purely philosophical point of view, the explanation they afford of the serpent-worship of Egypt is unsatisfactory in the extreme. ${ }^{(37)}$

$\left({ }^{34}\right)$ A. Erman\& H. Grapow, Wörterbuch der Aegyptischen Sprache Akademie-Verlag I (Berlin, 1971), 577, 8.

$\left({ }^{35}\right)$ J.E. Cirlot, A Dictionary of Symbols (London, 1962), 385.

$\left.{ }^{36}\right)$ G.Walker, Woman's Dictionary of Symbols and Sacred Objects, (New York, 1988), 527.

$\left({ }^{37}\right)$ M.D. Cooper, Serpent Myths of Ancient Egypt, Forgotten Books, (London, 2018), 16. The Middle East used to regard the female serpent as the embodiment of enlightenment, or wisdom, because she understood the mysteries of life. In Arabic, the words for "serpent" "life," and "teaching" are all related to the name of Eve-the biblical version of the Goddess with her serpent form. She gave the food of enlightenment to the first many Of course, in the Bible both Eve and her serpent were much diabolized; but 


\section{The benevolent Serpent Deities at the Underworld Book}

\section{The Divinity and Symbolic Value of the Serpent Fertility and Rebirth:}

In religion, myth, and literature, serpents often stand for fertility or creative life forces. They are said to be the symbols of life that throw off the past and continue to live. ${ }^{(38)}$ As when the ancient Egyptians would represent the universe, they delineate a serpent with variegated scales, devouring its own tail; by the scales intimating the stars in the universe. The animal is also extremely heavy, as is the earth, and extremely slippery, like the water. Moreover every year it puts off its old age with its skin, as in the universe the annual period effects a corresponding change. It becomes renovated to emerge again as these ability was confirmation of the belief in resurrection to the ancient sages' as the moon ${ }^{(39)}$ its shadow to be born again. The serpent and the moon are interchangeable in many cultures because both of them are immortal. They are in constant renovation and that is why the serpent is considered a representation of the moon. The serpent shed its skin periodically, it transforms, but it does not perish, it renews itself as the moon does. It teaches us about the cycle of life, death, and rebirth. Serpents teach us about vitality, sensuality, and fertility.

The serpents are closely associated with both of the males and females, in the same way they are related to the moon. Serpents have as well a deep fecundity symbolism. Some scholars think that the snake has a feminine side (lunar) and a masculine one, since its shape and its movements suggest the virility of the penis. So, serpents combine the two principles masculine and feminine needed for the creation. Anyway, in Ancient Egypt the phallic condition of the serpent does not seem to be too emphasized. ${ }^{(40)}$

Gnostic sects of the early Christian era retained some of the older ideas about their collaboration concerning the fruit of knowledge. Some sects worshiped the serpent as a benevolent Female Spiritual Principle, who taught Adam and Eve what they needed to know about God's duplicity (W. Barbara, Coptic Egypt (Edinburgh, 1988), 52).

$\left({ }^{38}\right) \mathrm{J}$. Garai, The Book of Symbols (London, 1974), 134.

$\left({ }^{39}\right)$ It is mentioned that the serpent is considered lunar creature, according to Andrews all animals that appear and disappear in a cyclic way (snails; reptiles; and bears) are considered lunar creatures (T. Andrews, Animal Speak (London, 2003), 360-363).

$\left({ }^{40}\right)$ W.B. Kristensen, Life out of Death. Studies in the Religions of Egypt and of Ancient Greece (Leuven, 1922), 21, 22. 


\section{Guardianship:}

The wisdom of the gods was the knowledge of the serpent. His sinuous form like the undulating waves of the sea which contain every secret and the mystery of life. ${ }^{(41)}$ Serpents are seen as potent guardians of temples and other sacred spaces. This connection may be grounded in the observation that when threatened. Some serpents (such as rattleserpents orcobras) frequently hold and defend their ground, first resorting to threatening display and then fighting, rather than retreat. They are natural guardians of treasures or sacred sites which cannot easily be moved out of harm's way. ${ }^{(42)}$

From the earliest records of civilization, the serpent played a significant cultural role as an enigmatic creature with supernatural powers. It is related with the Egyptian magic that have to be classed as Demonic. Since it invoked all manner of supernatural beings including the fearsome inhabitants of the underworld. ${ }^{(43)}$ It is alternatively seen (in the same community) as benevolent creator and protector of wisdom and eternal life, or perpetrator of evil and agent of death. ${ }^{(44)}$

\section{Good and Evil}

It seems clear that enough evidences exist from a wide range of sources to establish the dual nature of serpent symbols. ${ }^{(45)}$

This nature representing both gods and demons, good and bad, life and death. In some instances, serpents served as positive symbols with whom it is possible to identify or to sympathize. In other instances, serpents served as negative symbols, representing opponents or antagonists of figures or principles with which it is possible to identify. They also appeared as ambivalent figures, neither wholly positive nor wholly negative in valence.

$\left({ }^{41}\right) \mathrm{J}$. Garai, The Book of Symbols, 134.

$\left({ }^{42}\right)$ M. Lurker, Snakes and Staff Symbolism in Healing, Acta Theologica Supplementum 7 (London, 2005), 190-198.

$\left({ }^{43}\right)$ G. Pinch, Magic in Ancient Egypt (London, 1994), 15.

$\left({ }^{44}\right)$ U. Hendel, Serpent (Cambridge, 2002), 1404-1412.

(45)Evidence from all sources (scriptural, cultural, historical, and prophetic) leads us to believe that the serpent symbol appeared first in the Garden of Eden when Satan adopted the form of a snake, which was intended to point to the true Messiah. Over time, it's true meaning became corrupted not only as it became established through natural observation - the serpent shedding its skin and so on-but also as the symbol passed through many cultures down through the ages. The result, of course, was the appearance of the dual nature of serpent symbolism in the various civilizations of the Near East and elsewhere (M. Lurker, Acta Theologica, (London, 2005), 190-198. 


\section{The benevolent Serpent Deities at the Underworld Book}

Serpent were certainly not seen always a threatening creatures in ancient Egypt, as they seem to have been in other societies. In fact, they were frequently seen as protective and guardians. The serpent represents any primeval, cosmic force. It shares the ambiguity of all ancient, elementarysymbols (cf. Eagle, Lion, etc.); examples: the most spiritual of all creatures; it has a fiery nature, and its swiftness is terrible. ${ }^{(46)}$

\section{Poison and healing}

Serpents are connected with poison and medicine. Its venom is associated with the chemicals of plants and fungithat have the power to either heal poison or provide expanded consciousness (and even the elixir of life and immortality) through divine intoxication. Because of its herbal knowledge and entheogenic association the serpent was often considered one of the wisest animals, being (close to the) divine. Its divine aspect combined with its habitat in the earth between the roots of plants made it an animal with chthonic properties connected to the afterlife and immortality. ${ }^{(4)}$

At the time domestic serpents were also accepted by households as bringers of good fortune. They were commonly associated with wisdom and longevity.The heavy wooden staff was probably a symbol of eternity as embodied in mother earth, rather than representing the walking stick of the dedicated physician always ready to travel anywhere for the good of his patients. $^{(48)}$

Since time immemorial the serpent has been venerated as an enigmatic creature with supernatural powers. As a serpent and staff symbol it is also traditionally associated with the healing arts as he was an historical figure as healer in earlier ages in less certain. ${ }^{(49)}$

$\left({ }^{46}\right)$ M. Lurker, An Illustrated Dictionary, 108.

$\left({ }^{47}\right) \mathrm{J}$. Anthony, Serpent in the Sky. The High Wisdom of Ancient Egypt (United States of America, 1993), 137.

$\left({ }^{48}\right) \mathrm{J}$. Schouten, The Rod and the Serpent of Asclepius, Elsevier (Amsterdam, 1976), 118-120.

$\left({ }^{49}\right)$ Either as the single-serpent attribute of Asclepius, or as the double serpent attribute of Hermes. Inthis article the mythological basis for this symbol is reviewed. The Asclepian emblem has been associated with health care since the 5th century BC when Asclepius became accepted by the Greeks as the god of healing (M. Lurker, An Illustrated Dictionary, 370). 


\section{Conclusion}

The serpent is an animal of the earth. It lives in a caverns and hisses over the earth. Also outside Egypt the serpent is considered a chthonic animal in the tombs of the kings who is a symbol of the earth. The travelling of the sun through the underworld is represented as if the sun is drawn through a big serpent. Closely connected with the fear of the earth as realm of the dead is the fear of serpents, who have the earth as a residence. Many spells bear upon preventing the dead being bitten by serpents. Charms, which were used by living people as preventive against serpent bites, may also be applied in behalf of the dead.

As an animal of the earth it houses in the darkness of the realm of the dead. There is a big serpent, feared by the dead, called 23 hry h.t.f., "Big One which is on its Belly". It is represented in the 4th division of the krrtbook over the whole width of the register 1). The inscription to it reads: "This great god $(\mathrm{Re})$ enters the twilight. This great god passes the den of the big one, which is on its belly, whose head is in darkness and whose behind is in darkness, whose den the gods, spirits and dead do not approach and whom nobody passes except this great god, who is in heaven".

So, serpent is closely connected with the death which is considered the necessary condition for eternal life. Without death, no victory over death. Death becomes the foundation of eternal life, life in its potential form. The Egyptian orientated himself to nature for this monistic conception. There is a rhythm in vegetation: plants and crops mature and die down, but they spring up again from the seed which has been put into the earth and has died. After each setting the sun rises in the East through its own spontaneous power. This resurrection from death points to the fact that the secret of spontaneous life lives under the earth in the realm of the dead.

The Egyptian considered death the enemy of the good life on earth, which he loved and knew how to enjoy with a gay meal accompanied by play and dance. Concerning death all sorts of terms of fear and fright are used.

Not only the death but also the serpent as one of the great factors of the underworld. The continuity of life in ancient Egypt belongs to the entirely theological system that of the progress of the sun-god Ra who should be accompanied by a crew of large number. This souls went to join the setting sun in the west and prayed to be allowed to enter the boat of the sun in the company of the gods. They would be saved from the terrors and serpentdemons of the night over which the sun triumphed.

The nightly journey of the sun god was expressed most explicitly in the New Kingdom Royal Books of the Afterlife. During this journey, in order to 


\section{The benevolent Serpent Deities at the Underworld Book}

emerge from the twelve hours of night unscathed, he relied on protection from other entities. Although some of these were named deities, others play lesser parts in the pantheon; often we rely on simply a description or an image, especially in non-royal examples. In the Royal Books of the Afterlife, in particular those that emerged before the Amarna Period.Both the solar boat and the gates between hours are guarded by a large number of serpent-beings. Serpents are creatures that have a two-fold function in this specific type of literature: they are either guardians or they are malevolent and are usually identified as such by their descriptions in the texts.

It is important that the dead on his journey knows how to "pass" dangerous places safely as the dead goes unscathed along dangerous places ( $p r b 3 p f, s w r$ ) and sails to heaven. There are many places in the realm of the dead where the dead has a great deal to suffer. He is put on a slaughteringblock and killed like a piece of cattle. As a punishment he is put into a burning division of hell. He may fall into pools, which are usually full of serpents with firing flames as they (serpents) are responsible for the punishment by burning in the caldrons or copper basins. Certain spells help the dead to pass these dangerous places and their demoniacal guards. 


\section{Figures}

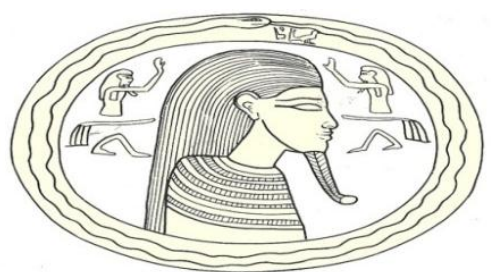

Fig.1, The sun god Ra is encircled by the protective serpent Mehen which seen eating its own tail as a symbol for the cycle of life and death that the universe maintains. After (R. Wilkinson, The Complete Gods, 223)

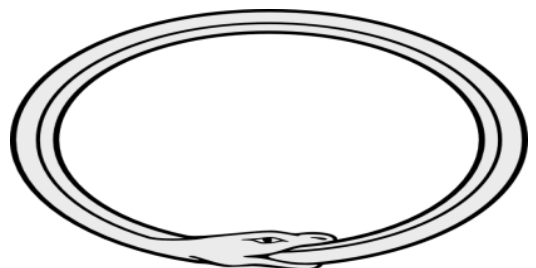

Fig.2, The scene represents a serpent described as the 'tail-eater' which is present in a variety of different cultures, going back as far as the ancient Egyptians.

After (R. John, From Alchemy to Chemistry (New York,1957), 179).

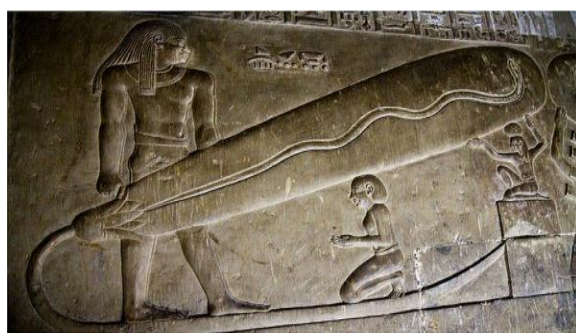

Fig.3, The full circle of the serpents' body portrayed as being surrounded the world in order to separate between the existence and nonexistence.

After, E. Hornung, Conceptions of God in Ancient Egypt: The One and the Many (London, 1996), 179.

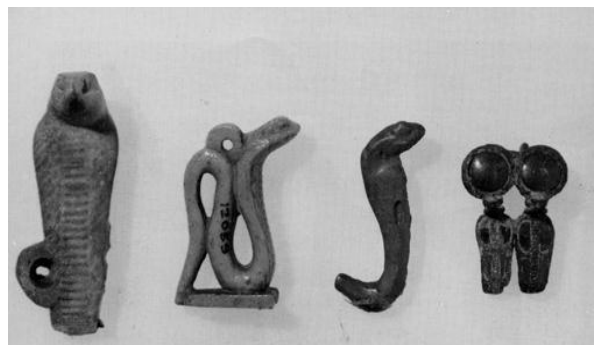

Fig.4, The four defensive forms of the uraeui named with the serpent goddesses who appear the amuletic form.

After, C. Andrews, Amulets of Ancient Egypt (London, 1994), 35. 


\section{The benevolent Serpent Deities at the}

\section{Underworld Book}

\section{References}

- Adde Vries, W., Dictionary of Symbols and Imagery (London,1997).

- Anthony, J.,A., Serpent in the Sky. The High Wisdom of Ancient Egypt, Quest Books (United States of America, 1993).

- Alexandridis, A., Wenn Götter Lieben, Wenn Götter Strafen, Mensch und Tier in der Antike (Leipzig, 2008).

-----, Mensch und Tier in der Antike: Grenzziehung und Grenzuberschreitung, Reichert Verlag (Wiesbaden, 2008)

- ----, Animals, Oxford Encyclopedia in Ancient Greece and Rome I, (Oxford, 2010), 108-112.

- Allen, J., The Art of Medicine in Ancient Egypt (London, 2005).

- Andrews, T., Animal Speak (London, 2003).

- Barbara, W., Coptic Egypt (Edinburgh, 1988).

- Baumann, A., The Suffix Conjugation of Early Egyptian as Evidenced in the Underworld Books I (Chicago, 1998).

- Bayley, H., The Lost Language of Symbolism, (London, 1995).

- Becker, U., The Continuum Encyclopedia of Symbols, Continuum (London, 1994).

- Burston, D., Freud, the Serpent \& the Sexual Enlightenment of Children III (New York, 1994).

- Cirlot, J., A Dictionary of Symbols (London, 1962).

- Cooper, M.D., Serpent Myths of Ancient Egypt, Forgotten Books (London, 2018)

- De Buck, A., The Egyptian Coffin Texts VII (Chicago, 1961).

- Del Valle, T., Gendered Anthropology (London, 1993).

- Francis, J.N., Ancient Egyptian Medicine (Oklahoma, 2002).

- Frankfort,H., Kingship and the Gods (Chicago, 1962).

- Friedrich, J.Q., The Animals of the Desert and the Return of the goddess, Desert Animals in the Eastern Sahara Colloquium Africanum 4 (Köln, 2009), 341-361.

- Garai, J., The Book of Symbols (London, 1974).

- Gardiner, A., Egyptian Grammar, Griffith Institute (Oxford, 1927).

- Geddes, C.L. \&G. Grosset, Ancient Egypt: Myth\&History, (Scotland, 1997).

- Hansen, N., 2001, Amphibians and Reptiles, Oxford Encyclopedia of Ancient Egypt 1, ed. D. Redford (Oxford, 2003), 74-75. 
- Hornung, E., Der Ägyptische Mythos von der Himmelskuh: Eine Ätiologie des Unvolkommenen Orbis Biblicuset Orientalis 46 (Göttingen, 1982).

- Houlihan, P.F., The Animal World of the Pharaohs (New York, 1996).

- Jackal, G., Theriomorophic Egyptian Gods (New York, 2003).

- Jobes, G., Dictionary of Mythology (London, 1961).

- Johnson, S., The Cobra Goddesses of Ancient Egypt: Pre-dynastic, Early Dynastic, and Old Kingdom Period (London, 1990).

- Kees, H., Toten Glauben und Jenseitvorstellungen der Alten Ägypter: Grundlagen und Entwicklung bis zum Ende des Mittleren Reiches (Berlin, 1956).

- Kristensen, W.B., Life out of Death. Studies in the Religions of Egypt and of Ancient Greece (Leuven, 1992).

- Linda, E., Animal Behavior in Egyptian Art: Representation of the Natural World in Memphite Tomb Scenes (Australian Centre for Egyptology, 2010).

- Lurker, M., An Illustrated Dictionary of the Gods and Symbols of Ancient Egypt (London, 1982).

- Martin, F., Tierkulte im Pharaonischen Ägyptischen Ägypten, Ägyptologie und Kulturwissenschaft VI (München, 2013).

- Moscati, S., The Face of the Ancient Orient Garden City (Chicago, 1962).

- Münster, M., Untersuchungen zur Göttin Isis vom Alten Reich bis zum Ende des Neuen Reiches, Muenchner Äegyptologische Studien 11 (Berlin, 1968).

- Nunn, J.F., Ancient Egyptian Medicine (Oklahoma, 1996).

- Pinch, G., Magic in Ancient Egypt (London, 1994).

- Régen, I., 2015, Documents de Théologies 13 (Montpellier, 2015).

- Sauneron, S., Papyrus MagiqueIllustre de Brooklyn, du Brooklyn Museum (New York, 1980).

- Schouten, J., The rod and the serpent of Asclepius, Elsevier (Amsterdam, 1967).

- Sethe, K., Die Altaegyptische Pyramidentexte: nach den Papierabdrücken und Photographien des Berliner Museums (Leipzig, 1922).

- Walker, G., Woman's Dictionary of Symbols and Sacred Objects, Harper One (New York, 1988). 


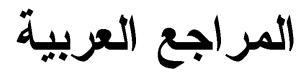

ـ أحمد بدوي، هيرودوت يتحدث عن مصر (القاهرة، 9 ( IV).

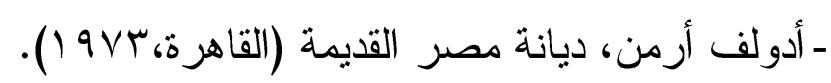

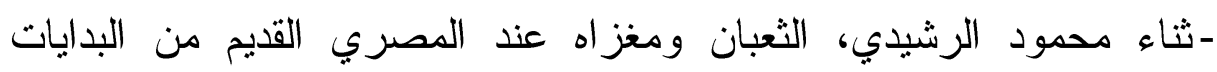

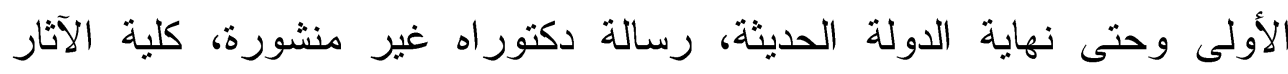

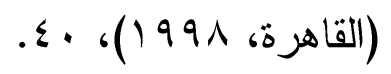




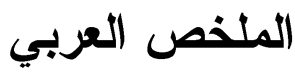

ظهرت بو ادر تقديس أو عبادة الحيوان في مصر منذ عصور ما قبل التاريخ،

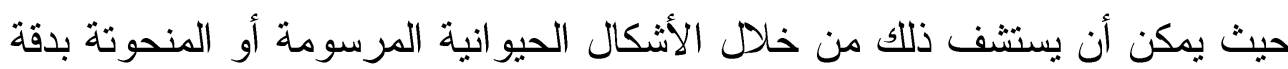

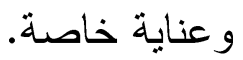

وقد عثر في العديد من المناطق الحضارية لهذه العصور على دفنات لحيو انات، ولعل ما حظيت به هذه الدفنات من عناية ملفتة، وما وضع معها داخل المقابر من قر ابين، يمكن أن يساق كدليل على وجود تقديس و عبادة لهذه الحيو انات،

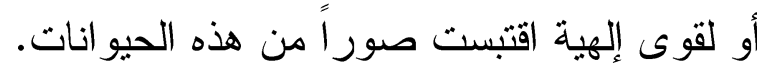
وفى ضوء ذلك بمكن استتاج أن المصريين قد عبدوا قوى إلهية في صورٍ وهيئاتٍ حيو انيةٍ منذ عصور ما قبل التاريخ، وإن لم بصل الأمر إلى درجة العبادة

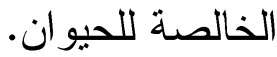

وقد برجع تقديس الإنسان للحيوان وعبادته في العصور المبكرة من التاريخ إما إلى الاستفادة و النفع منه، أو للخوف و الرغبة في دفع شره عنه. وقد برز تقديس

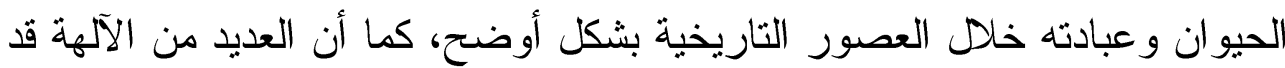
اتخذت هيئات حيو انية، أو مزيجاً بين الهيئة الحيو انية و البشرية.

فإن الديانة والفكر الديني هما مركز التقل في الحضارة المصرية القديمة فلولا إيمان المصري بأنه يعيش لفترة مؤفتة ويموت لفترة مؤقتنة، ثم يبعث من جديد حياةً

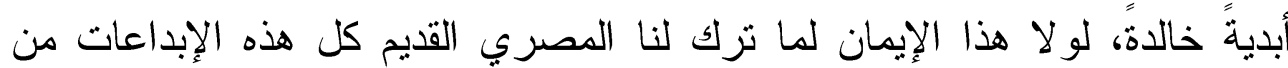

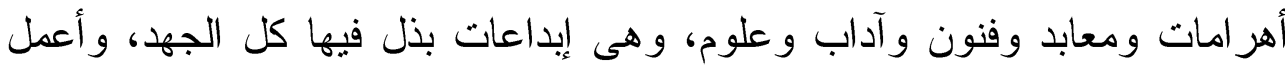

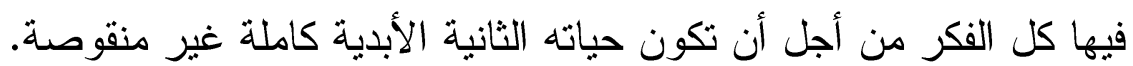

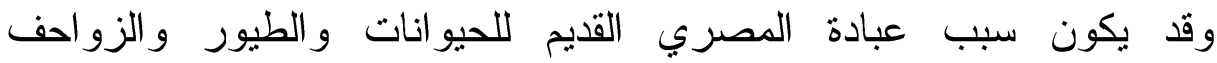
والأشجار وغيرها من الموجودات أنها قوى خفية لم يسنطع أن يدركها بآفاقه المدودة في أولى مر احل حياته. 


\section{The benevolent Serpent Deities at the}

\section{Underworld Book}

وتثير الظواهر أن المصري القديم لم يعبد هذه الموجودات لذاتها، و إنما على ألى

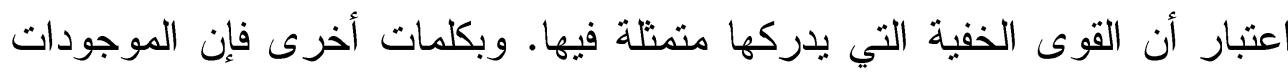

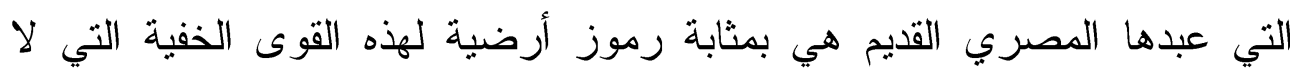

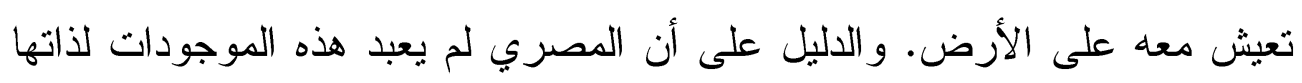

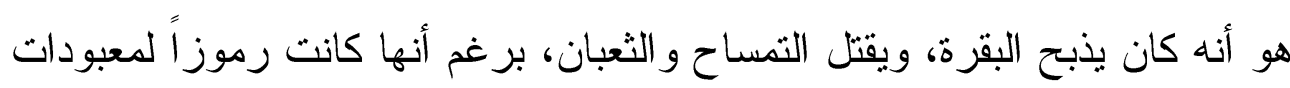
قدسها على مر العصور.

وقد تطور هذا الفكر بشكل مذهل، إذ سبق الإنسان المصري غيره في الاعتقاد

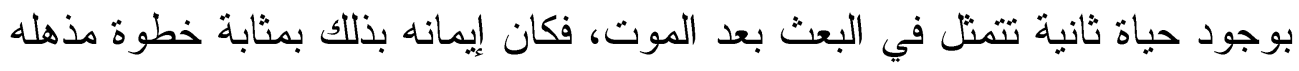

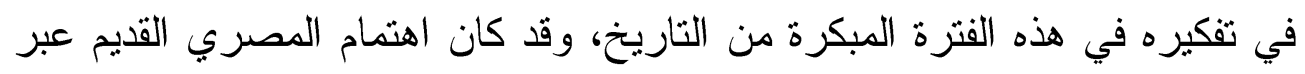

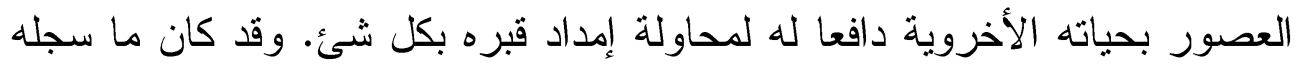

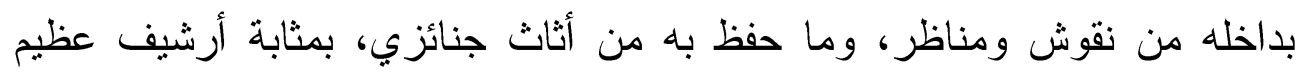
حفظ لنا تاريخ أقدم و أعظم الحضار ات.

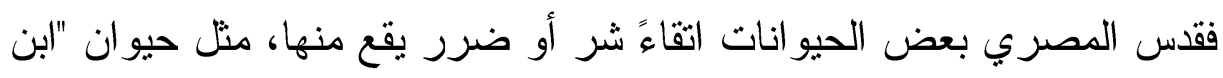

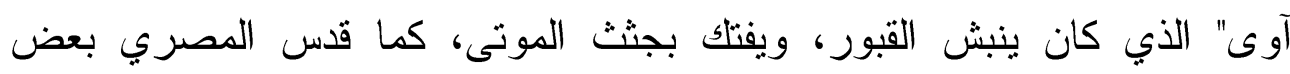

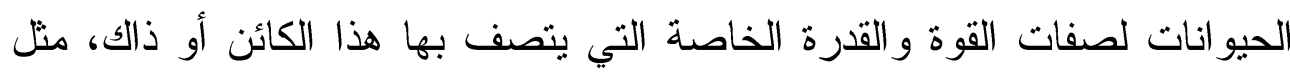
الثعبان لقدرته على الحر اسة و الحماية و الفتلك بأعدائه.

كما كان تقديس بعض الحيو انات لطبيعتها المميزة في أمر من الأمور ، كالثعبان

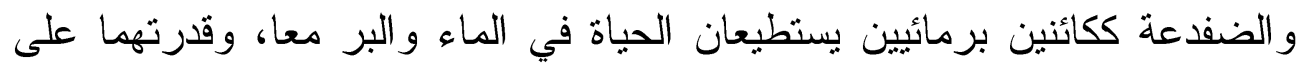

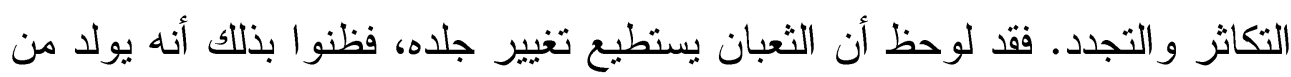

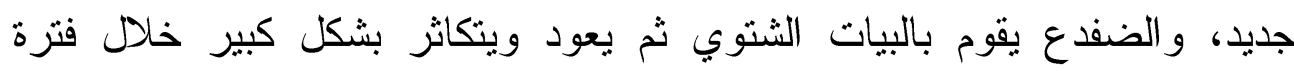

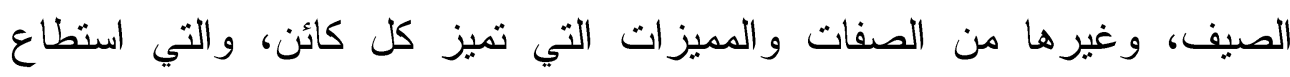

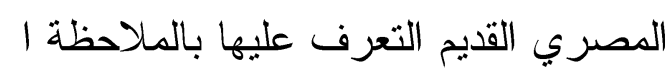

